\title{
A Posthuman-Xenofeminist Analysis of the Discourse on Autonomous Weapons Systems and Other Killing Machines
}

\section{Emily Jones ${ }^{1}$}

In this article, I critique the current debates surrounding autonomous weapons systems, using feminist posthuman theory to make sense of such systems - and the relation between human and machine - in terms of automation and autonomy. The dominant narratives about autonomous weapons tend to present them as exceptional; distinct from all the other kinds of human inventions that can kill. Further attention is required, not on autonomous weapons themselves but on the delegation of killing to a far broader range of technologies across the human-machine/autonomous-automated spectrum. While current attempts at legal regulation distinguish between civil and military technologies, such a distinction becomes impossible in light of the links between civil and military technologies and the killing potential of many technologies, including artificial intelligence.

Keywords: autonomous weapons systems, human enhancement technologies, artificial intelligence, xenofeminism, military technologies, feminism, posthuman

\section{Contents}

1.0 Feminist Posthuman Theory and Xenofeminism.....................................................

2.0 Automation, the Autonomous and the Artificially Intelligent ................................... 8

3.0 Legal-Ethico Debates on Autonomous Weapons Systems ........................................... 11

4.0 An Analysis of the Discourse on Autonomous Weapons Systems................................. 15

4.1 Challenging the Humanist Discourse around Autonomous Weapons: A Posthuman Analysis... 15

4.2 Machine-Human Life/Death Decision Making .............................................................. 17

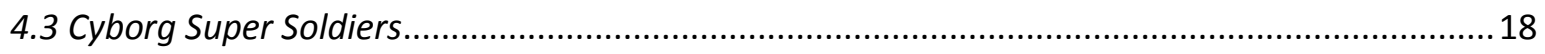

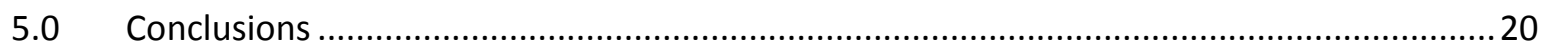

\footnotetext{
${ }^{1}$ Emily Jones, Lecturer in Law at the University of Essex: e.jones@essex.ac.uk. This article has benefited from the insights of Gina Heathcote, Yoriko Otomo, Safet Hadzimuhamedovic, Sara Kendall and Chris Willett. An earlier version of this paper was presented at the Law and Society Association (LSA) International Meeting in Mexico City in June 2017. Another version was also presented at the Against the Slow Cancellation of the Future Conference at the Centre for Cultural Studies at Goldsmiths in London, also in June 2017. I was also fortunate enough to be able to present an almost final version of this paper to the Human Rights Clinic at the University of Essex in 2018. I would like to thank those in attendance at all these presentations for their engagement and helpful insights. I would also like to thank my anonymous reviewers for their invaluable comments. All errors remain my own.
} 


\subsection{Feminist Posthuman Theory and Xenofeminism²}

Global military spending has been estimated by the Stockholm International Peace Research Institute (SIPRI) to have been around US\$1.6 trillion in $2016 .{ }^{3}$ The military economy is not, however, just about state spending: direct and indirect employment within the U.S. aerospace and defence industry alone includes approximately 3.53 million people. ${ }^{4}$ Feminist scholars have highlighted how militarism goes further in that there are a number of key roles often played by women outside the formal work place. ${ }^{5}$ Militarisation can be seen as both creating and profiting from informal (unpaid) work by women, which also produces and maintains gender difference.

In addition, military spending benefits companies. It does not, as two peace scholars point out, 'compete directly with private investment. It supplements but does not supplant the private sector. Thus, its expansion will not undermine business confidence' ${ }^{6}$ The military economy is a fast-moving one, creating continuous profits as technology advances and systems need replacing. ${ }^{7}$ Military development spending has increased over the past decade in many states including the U.S., Kenya, Brazil, Colombia, India, Malaysia, Poland and Russia. $^{8}$

Much of this war economy is driven by the development and deployment of technology, which reaps profits not only through military use but also often later through civil use. Satellite navigation is a prime example of this. ${ }^{9}$ While existing weapons systems such as the PAC-3 and the Samsung SGR-A1 described below are more automated than autonomous, 'there are significant global efforts in the research and development (R\&D) of autonomous

\footnotetext{
${ }^{2}$ While Haraway is wary of naming herself a posthumanist due to her wish, not to become post-human but rather to de-centre the human and look towards multi-species becoming, I have defined her as such. This is because her concerns and perspectives align with the type of posthumanism I use in this thesis and which others, such as Braidotti, use, i.e. a posthumanism which both works in continuum with and beyond humanism itself. See; Donna Haraway, 'Tentacular Thinking: Anthropocene, Capitalocene, Chthulucene' (2016) 75 e-flux <http://www.e-flux.com/journal/75/67125/tentacular-thinking-anthropocene-capitalocene-chthulucene/> (accessed 26 November 2017); Rosi Braidotti, The Posthuman (Polity Press 2013) 38.

In addition to this, Helen Hester, one member of the xenofeminist collective Laboria Cuboniks, has also expressed that she does not see xenofeminism as aligning with posthumanism. Again, however, I define xenofeminism as posthuman in the postructuralist-inspired sense of posthumanism - there are clear cross-overs between the two. See Helen Hester and Diann Bauer, Xenofeminism: A Politics for Alienation paper presented at SOAS, University of London, 11 January 2018.

See also Laboria Cuboniks, Xenofeminism: A Politics for Alienation (online) 〈http://www.laboriacuboniks.net/> (accessed 21 September 2017).

3 Stockholm International Peace Research Institute (SIPRI), Military Expenditure Database (online) http://www.sipri.org/research/armaments/milex/milex_database/milex_database (last accessed 02 December 2017). Statistic taken from global military expenditure from the year 2016 (latest figure in current US\$).

${ }^{4}$ Deloitte report sponsored by the Aerospace Industries Association (AIA), The Aerospace and Defence Industries in the U.S. (online) $2012<\mathrm{http}: / /$ armedservices.house.gov/index.cfm/files/serve?File_id=126226cdbc54-4e4b-a9ec-1ea16e61a2dd> (accessed 11 March 2016). Statistic is for the year 2010.

${ }^{5}$ Cynthia Enloe, Maneuverers: The International Politics of Militarizing Women's Lives (California University Press 2000) at 44.

${ }^{6}$ Miroslav Nincic and Thomas R. Cusack, 'The Political Economy of US Military Spending' (1979) 6(2) Journal of Peace Research 101 at 112.

7 Nincic and Cusack, as above at 112; P. Dunne, 'The Political Economy of Military Expenditure: An Introduction' (1990) 14 Cambridge Journal of Economics 395 at 398.

${ }^{8}$ SIPRI above note 3 .

9 Aeronautics and Space Engineering Board et al, The Global Positioning System: A Shared National Asset (National Academies Press 1995).
} 
systems' ${ }^{10}$ Artificial intelligence and machine learning technologies have seen considerable advancement in the commercial sector, which is leaving the military sector behind. ${ }^{11}$ States are beginning to note the need to "catch up with Silicon Valley". "Seeking to tap into the advancements made in the commercial sector, the creation of weapons systems with some level of autonomy has recently become a key focus for the U.S. Department of Defense through Project Maven. When establishing the project in 2017, the U.S. Deputy Secretary of Defense Robert O. Work stated that 'the Department of Defense (DoD) must integrate artificial intelligence and machine learning more effectively across operations to maintain advantages over increasingly capable adversaries and competitors'. ${ }^{13}$ While Project Maven is currently focusing on the incorporation of algorithms into military operations, reflecting the current state of technological advancement, it seeks to consider and promote 'all initiatives that develop, employ, or field, artificial intelligence, automation, machine learning, deep learning and computer vision algorithms'. ${ }^{14}$ In other words, Project Maven is not only creating more complex algorithms but is also actively seeking to ensure that the U.S. is at the forefront of the development of autonomous weapons technologies.

In this paper I argue that feminist posthumanist theory is an important paradigm through which to understand our relationship to technology, and to autonomous weapons systems in particular. Feminist posthumanism uses technology (alongside the nonhuman animal and matter) to question what it means to be human, deconstructing the very notion of what the human is, noting that the concept of the human in dominant Western accounts of subjectivity creates hierarchies between humans as well as between the human and other living beings. ${ }^{15}$ A clear example of the way in which feminist posthuman theory challenges humanist accounts of subjectivity can be seen in Donna Haraway's work. Haraway notes that humans are already cyborgs in that they are deeply connected to, desire, and are dependent upon technology. ${ }^{16}$ Such an understanding of technology is essential to understanding autonomous weapons systems. In noting the connection between the human and machine and deconstructing distinctions between autonomy and automation, a posthuman perspective on autonomous weapons foregrounds the need to focus not only on autonomous weapons but on the broad array of delegated killing. While current attempts at legal regulation distinguish between civil and military technologies, such a distinction becomes impossible in light of the clear links between civil and military technologies and the killing potential of many

\footnotetext{
${ }^{10}$ M.L. Cummings, 'Artificial Intelligence and the Future of Warfare' (2017) Chatham House 1 at 9. Available online at <https://www.chathamhouse.org/sites/files/chathamhouse/publications/research/2017-01-26-artificialintelligence-future-warfare-cummings-final.pdf> (accessed 18 February 2018).

${ }^{11}$ Cummings as above.

12 Stew Magnusun, DoD Making Big Push to Catch Up on Artificial Intelligence (online) 13 June 2017 $<$ http://www.nationaldefensemagazine.org/articles/2017/6/13/dod-making-big-push-to-catch-up-on-artificial-

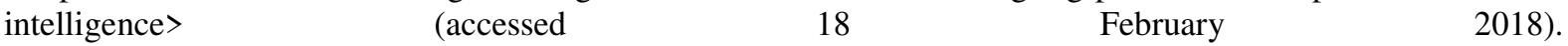
The active inclusion of commercial players and researchers is also the aim of the U.S. Defense Enterprise Science Initiative (DESI). See MeriTalk, DoD Wants to Expand Collaboration with Industry (online) 12 January 2018 <https://www.meritalk.com/articles/dod-wants-to-expand-collaboration-with-industry/> (accessed 18 February 2018).

${ }^{13}$ Robert O. Work, U.S. Deputy Secretary of Defense, Memorandum on the Establishment of an Algorithmic Warfare Cross-Functional Team (Project Maven) 26 April 2017. Available online at <https://www.govexec.com/media/gbc/docs/pdfs_edit/establishment_of_the_awcft_project_maven.pdf. (accessed 18 February 2018).

${ }^{14}$ As above.

${ }^{15}$ See generally, Braidotti above note 2; Stacy Alaimo and Susan Hekman (eds) Material Feminisms (Indiana University Press 2008).

${ }^{16}$ Donna Haraway, 'A Cyborg Manifesto' in David Bell and Barbara M. Kennedy (eds) The Cybercultures Reader (Routledge 2001) 291.
} 
technologies, including artificial intelligence (AI). ${ }^{17}$ This article therefore contributes to legal studies as well as the discourse on autonomous weapons. It further contributes to feminist approaches to international law, inserting such approaches into the realm of military technologies and highlighting the relevance of feminist approaches to all areas of international law. ${ }^{18}$

Law and gender theory is an important lens through which to analyse military technologies. ${ }^{19}$ Military technologies touch on several political and philosophical issues that gender theorists have long discussed. Legal articulations of subjectivity in particular are something that feminist legal theory has long problematised, and is directly relevant to the question of the 'legal person' as machines become more and more autonomous. ${ }^{20}$ This may require legal change to allow for 'electronic' subject-recognition. ${ }^{21}$ In addition to this, gender theories have developed a nuanced set of tools through which to analyse issues around inclusion, exclusion and justice. This can be seen in gender theory's commitment to intersectionality, which looks at gender alongside race, sexuality, ability, class, etc. ${ }^{22} \mathrm{~A}$ gender perspective ensures the consideration of the multiple ways in which technologies may impact on intersecting groups, which may be missed in mainstream discussions about the use of autonomous weapons systems.

Despite the many debates on autonomous weapons, there has been little consideration of such systems from a feminist posthuman perspective. ${ }^{23}$ Mary Manjikian appears to be the only

\footnotetext{
${ }^{17}$ For example, while the European Parliament has called for the greater regulation of new technologies, their proposals specifically focus on civil technologies. The resolution does not seek to address military technologies and the issues they may pose, thus posing the civil and the military as distinct. See European Parliament Resolution of 16 February 2017 with recommendations to the Commission on Civil Law Rules on Robotics, (2015/2103(INL)).
}

Cummings has noted that commercial developments in technology are likely soon to be so high tech that the regulation of military technologies may become nonsensical given the ways in which commercial tech could potentially soon be easily moderated and developed. See Cummings above note 10.

${ }^{18}$ See Hilary Charlesworth, Gina Heathcote and Emily Jones, 'Feminist Scholarship on International Law in the 1990s and Today: An Inter-Generational Conversation between Hilary Charlesworth, Gina Heathcote and Emily Jones' (Forthcoming 2018) Feminist Legal Studies.

19 Yoriko Otomo's work is key in seeking to note the links between technological development, military technologies and the post-war international law settlement, analysing these things from a feminist perspective. See Yoriko Otomo, Unconditional Life: The Postwar International Law Settlement (Oxford University Press 2016).

${ }^{20}$ Ngaire Naffine, 'The Body Bag' in Ngaire Naffine and Rosemary Owens (eds) Sexing the Subject of Law (LBC Information Services 1997) 79; Anna Grear, "Sexing the Matrix': embodiment, disembodiment and the law - towards the re-gendering of legal rationality' in Jackie Jones, Anna Grear, Rachel Anne Fenton and Kim Stevenson (eds) Gender, Sexualities and Law (Routledge 2011) 39; Ngaire Naffine, 'Women and the Cast of Legal Persons' in Jackie Jones, Anna Grear, Rachel Anne Fenton and Kim Stevenson (eds) Gender, Sexualities and Law (Routledge 2011) 15.

${ }^{21}$ For example, the European Parliament has called for the recognition of 'electronic persons'. See; European Parliament above note 17.

${ }^{22}$ See for example Kimberle Crenshaw, 'Mapping the Margins: Intersectionality, Identity Politics, and Violence Against Women of Color'(1991) 43(6) Stanford Law Review 1241; Angela Y. Davis, Women, Race \& Class (Ballantine Books 2011); Sadie Wearing, Yasmin Gunaratnam and Irene Gedalof, 'Frailty and Debility' (2015) 111(1) Feminist Review 1; Judith Butler, Gender Trouble (Routledge 2006).

${ }^{23}$ On some of these debates see, for example, Robert Sparrow, 'Robots and respect: Assessing the case against Autonomous Weapon Systems' (2016) 30(1) Ethics and International Affairs 93; Peter Asaro, 'On Banning Autonomous Weapons Systems: Human Rights, Automation, and the Dehumanization of Lethal DecisionMaking' (2012) 94(886) International Review of the Red Cross 687; Armin Krishnan, Killer Robots: Legality and Ethicality of Autonomous Weapons (Routledge 2009); Benjamin Kastan, 'Autonomous Weapons Systems: A Coming Legal Singulaity' (2013) 1 45; Marcus Schulzke, 'Autonomous Weapons and Distributed Responsibility' (2013) 26(2) Philosophy \& Technology 203; Jack M. Beard, 'Autonomous Weapons and 
scholar who has sought to apply feminist posthumanism to the realm of autonomous technology. ${ }^{24}$ Manjikian discusses the ways in which military technologies may be used to create either a less or a more militarised world, concluding that technology is more likely to create a more militarised, hyper-masculine world. ${ }^{25}$ Heeding Manjikian's suspicion of the hyper-masculinity of militarism, this article works in the vein of Haraway and other feminist posthuman thinkers such as Rosi Braidotti and the 'xenofeminists', a collective of scholars working under the name 'Laboria Cuboniks' who seek to use and appropriate technology for feminist aims - to think critically about the significance of autonomous weapons systems, for the ways in which law fashions our understanding of human subjectivity. ${ }^{26}$ This paper adds to the discourse on autonomous weapons by proposing a xenofeminist posthuman perspective, providing a different way of understanding these systems while contributing to the development of feminist approaches to international law.

While Haraway is fundamentally positive about technology's potential to be used for feminist aims, she notes that feminists must also ensure that technology is not used to create 'the final abstraction embodied in a Star Wars apocalypse waged in the name of defence, about the final appropriation of women's bodies in a masculinist orgy of war. ${ }^{27}$ Haraway also notes that technology is embedded within capitalism, pointing out the fact that the people usually making the machines are often poor women from the Global South. ${ }^{28}$ Haraway's work seeks to create a feminist techno-future in spite of and while trying to avoid the risks of a possible hyper-masculine techno-future. While Haraway seeks to promote the use of technology for feminist aims, the Xenofeminist Manifesto (XFM) has a more focused feminist project in mind. The XFM seeks to destroy capitalism through the accelerated use of technology to create a post-work world, thereby directly advocating for post-capitalism as a feminist aim. ${ }^{29}$ Thus, the XFM insists not only on the need to accelerate our use of/dependence upon technology, but also to appropriate this technology for feminist aims, ensuring that such technology remains loyal to the politics they wish it to promote. Such feminist aims include the will to ensure the free distribution of hormones or the will to use technology to restructure gendered systems of reproductive labour and care. ${ }^{30}$ While the xenofeminists note

Human Responsibilities' (2014) 45(3) 617; Heather M. Roff, 'The Strategic Robot Problem: Leathal Autonomous Weapons in War' (2014) 13(3) 211; Peter Scharre, 'Autonomous Weapons and Operational Risk' (2016) Ethical Autonomy Project 1.

${ }^{24}$ Mary Manjikian, 'Becoming Unmanned: The Gendering of Lethal Autonomous Warfare Technology' (2014) 16(1) International Feminist Journal of Politics 48.

${ }^{25}$ Manjikian as above.

26 The Xenofeminist Manifesto, an online manifesto released in 2015 which was written by a collective of unnamed scholars and practitioners, is the only current text on xenofeminism outside of interviews and talks given by some of the collective. One of the members of the collective, however, Helen Hester, does soon have a book coming out about xenofeminism. See Laboria Cuboniks, above note 2; Helen Hester, Xenofeminism (Polity Press forthcoming 2018).

In addition to this, feminist posthumanist scholar Rosi Braidotti discusses xenofeminism in her forthcoming book. See Rosi Braidotti, Posthuman Feminism (Polity Press forthcoming 2018).

${ }^{27}$ Haraway above note 15 at 29; Anna Feigenbaum, 'From cyborg feminism to drone feminism: Remembering women's anti-nuclear activisms' (2015) 16(3) Feminist Theory 265 at 271.

${ }^{28}$ Haraway above note 16; For more on the inequalities of tech see also; Laboria Cuboniks above note 2 at Interrupt $0 * 08$.

${ }^{29}$ In addition to this, the XFM looks to overcome global inequalities by centring intersectionality, aiming to create a more just, post-capitalist world. See Laboria Cuboniks above note 2 at Interrupt 007, Carry 013, Zero $0 * 00$, Parity $00 \mathrm{~F}$.

The XFM was written, in part, as a response to the Accelerate Manifesto. See; Alex Williams and Nick Srnicek, \#ACCELERATE MANIFESTO for an Accelerationist Politics (online) Critical Legal Thinking 2013 $<$ http://criticallegalthinking.com/2013/05/14/accelerate-manifesto-for-an-accelerationist-politics/> (accessed 14 February 2018).

${ }^{30}$ Laboria Cuboniks as above at Carry $0 * 16$. 
the dilemmas technology brings and the need to 'explicit[ly] acknowledge... these conditions as a target for elimination', they do not address the fact that the creation of a post-capitalist world will not be not immediate. ${ }^{31}$ In the meantime, as Haraway notes, science and technology have both contributed to and changed the face of 'late capitalism', with more work becoming precarious and being done at home, which affects women and people of colour most. ${ }^{32}$ Technology is largely designed by (and profits) people who are white, male and living in the Global North, while the raw materials are mined and manufactured elsewhere, by others. ${ }^{33}$

While some xenofeminist scholars propose the ubiquitous use of technology as the way to a feminist future, that future is less utopic when one considers that much technology is developed, first and foremost, for military purposes. ${ }^{34}$ While there has not yet been a feminist posthuman reading of autonomous weapons systems which seeks to dissect the false binaries upheld within the debates on these weapons between the human-machine and autonomyautomation, there has been some limited engagement with these systems from a feminist perspective by NGOs, one example being the Women's International League for Peace and Freedom's disarmament programme, 'Reaching Critical Will'. They consider the masculine nature of militarism and the ways in which this would only likely get worse if machines stripped of empathy engage in killing, instead of soldiers in face-to-face combat. ${ }^{35}$

It is interesting to note that many of the posthuman perspectives which currently exist on the topic of conflict and technology do come from a gender perspective. These works come from outside the legal discipline, however, and tend to focus on drone warfare. ${ }^{36}$ Posthuman theory, however, could have a key impact if applied to legal studies and the debates around autonomous weapons. ${ }^{37}$ In refusing to see the machine as other, noting the links between the

One way in which hormones can be appropriated, drawing on xenofeminist methods to re-appropriate science and technology and make it our own, can be through creating home grown hormones and teaching others the same know-how. The project Open Source Gender Codes is one such example of this. The project aims to create plants which would allow people to grow their own sex hormones at home. This project, if it or something like it succeeds, would not only massively challenge the pharmaceutical industry who produce these hormones, but would also allow people to make safe choices about whether or not they wish to take hormones outside the institutional contexts of the state and medicine. This could also, potentially, drastically change cultural attitudes to the taking of hormones, making transitioning more culturally acceptable due to its accessibility and lack of institutional framework. See Open Sources Gender Codes (online) $<$ http://opensourcegendercodes.com/projects/osg/> (accessed 2 December 2017).

On re-thinking care, see Hester and Bauer, above note 2.

${ }^{31}$ As above at Interrupt $0 * 08$.

${ }^{32}$ Haraway above note 5 .

${ }^{33}$ This inequality is exemplified by the way in which facial recognition technology has recently been shown to have trouble recognising black faces, as it has been created by and for a white elite.

See the Algorithmic Justice League, a project, led by Joy Buolamwini, which aims to fight bias in algorithms: <https://www.ajlunited.org/> (accessed 18 September 2017).

${ }^{34}$ As was the case with Satellite Navigation technology.

${ }^{35}$ Reaching Critical Will, WILPF Statement to the 2016 CC Meeting of Experts on Lethal Autonomous Weapons Systems (online) <http://www.reachingcriticalwill.org/resources/statements/10788-wilpf-statement-to-the-2016ccw-meeting-of-experts-on-lethal-autonomous-weapon-systems> (accessed 13 February 2018).

${ }^{36}$ See Cara Daggett, 'Drone Disorientations: How "Unmanned" Weapons Queer the Experience of Killing in War' (2015) 17(3) International Feminist Journal of Politics 361; Lauren Wilcox, 'Drone warfare and the making of bodies out of place' (2015) 3(1) Critical Studies on Security 127; Lauren Wilcox, 'Embodying Algorithmic War: Gender, Race and the Posthuman in Warfare' (2016) Security Dialogue 1; Lauren Wilcox, 'Drones, Swarms and Becoming-Insect: Feminist Utopias and Posthuman Politics'(2017) 116(1) Feminist Review 25.

${ }^{37}$ While there have been those who note the need to pay attention to the delegation of decision-making to technologies, such approaches have not, as far as this author is aware, been applied in conjunction with 
machine and the human, a posthuman approach would refuse the exceptionalism promoted by existing discourses on autonomous weapons, allowing for discussions to encompass a wider range of human-machine life/death decision-making. Killing machines may not be created as killer robots but may come into existence through other civil or military technological developments, such as artificial intelligence (AI) which may not have been designed to kill, but may ultimately be used to kill. ${ }^{38}$ More mundane but equally dangerous are developments in algorithm-driven decision-making. ${ }^{39}$ Further to this, given the vast advances in wearable military technologies and human enhancement technologies, a killer machine of the dystopian kind envisaged by many NGOs may, in fact, come about through technologically enhancing soldiers and turning them into superhuman soldiers. While such cyborg soldiers would not be deemed autonomous weapons under existing understandings of such systems, they will beg the same ethical questions around control and accountability, something which has not yet been recognised by the existing work on autonomous weapons. After all, at what point does a technologically mediated human become more machine than human?

While job automation may indeed help create a post-work, post-capitalist society, ${ }^{40}$ such systems pose vast ethical issues around control and accountability. 'Fully automated luxury communism' seems less luxurious in the face of machines taking professional killing jobs. ${ }^{41}$ Drawing on the XFM, this article concludes by proposing the need for a posthumanxenofeminist discourse on autonomous weapons systems and other civil and military technologies. This means that we do not need to 'abandon' technology, but rather to use it warily, drawing on the wisdom of intersectional critiques and seeking a post-capitalist vision of society. ${ }^{42}$ This article therefore makes several key contributions. First, the paper adds to the debate on 'autonomous' weapons by challenging existing definitions of such systems. The paper also analyses the international debates on these systems from the as-yet unapplied perspective of posthuman-xenofeminism, highlighting both what feminist posthuman and xenofeminist theory may add to the debates on autonomous weapons systems. Further, this article adds to feminist approaches to international law by situating them within discussions of autonomous weapons, proposing a new posthuman-xenofeminist methodology for such approaches. I conclude that there is a need for feminist posthuman intervention into the legal regulation of all technologies - one that understands the ways in which humans-machines work in connection while seeking to prevent the creation of all killer machines, thereby refusing current attempts at technological legal regulation which distinguish between civil and military technologies. ${ }^{43}$

posthuman theory nor applied to autonomous weapons systems. See; Sheila Jasanoff, The Ethics of Invention: Technology and the Human Future (W. W. Norton \& Company 2016).

38 Nick Land, Meltdown (online) Cybernetic Culture Research Institute <http://www.ccru.net/swarm1/1_melt.htm> (last accessed 02 December 2017). Cummings has also noted how, in recent years, the commercial sector's development of technologies has begun to outstrip military sector's development. See Cummings above note 10.

${ }^{39}$ Fleur Johns, 'Global Governance through the Pairing and List of Algorithm' (2016) 34(1) Environments and Planning D: Society and Space 126.

${ }^{40}$ For more on this see; Williams and Srnicek, above note 29; Calum Chace, The Economic Singularity: Artificial Intelligence and the Death of Capitalism (Three Cs 2016).

${ }^{41}$ See Aaron Bastani, Fully Automated Luxury Communism (Verso Books forthcoming 2018).

42 Haraway above note 16; Dianne Otto, "A Sign of "Weakness"? Disrupting Gender Certainties in the Implementation of Security Council Resolution 1325' (2006) 13(1) Michigan Journal of Gender and Law 113; Gina Heathcote, The Law on The Use of Force: A Feminist Analysis (Routledge 2012).

${ }^{43}$ As per; European Parliament above note 17; Campaign to Stop Killer Robots, Summary of CCW meetings in FAQs ahead of the CCW 2016 meeting on LAWS (online) 2016 <http://www.stopkillerrobots.org/2016/04/thirdccw/> (accessed 8 April 2017). 


\subsection{Automation, the Autonomous and the Artificially Intelligent}

There are currently a few definitions for autonomous weapons. The U.S. and U.K. governments, the UN Special Rapporteur on Summary or Arbitrary Execution and Human Rights Watch all use a similar definition: 'robotic weapon systems that, once activated, can select and engage targets without further intervention by a human operator. ${ }^{44}$ It is important to note that the definition must include 'once activated', as human control is always present when making and programming the machine. Full autonomy cannot be reached without the machines programming, designing and making themselves. Autonomous weapons are not drones. Drones are pilotless vehicles controlled remotely by humans. Autonomous weapons 'go considerably further than drones': ${ }^{45}$ they would have no human guidance after being programmed, either being controlled through high-level algorithms or through artificial intelligence. Autonomous weapons thus potentially range from programmed sentry guns to intelligent humanoid soldier-robots. Whilst it is broadly agreed that autonomy has yet to be achieved, research is on-going in this area. ${ }^{46}$ Most agree that autonomous weapons do not yet exist. However, this is somewhat debatable depending on the way autonomy is defined.

Robotic systems of varying levels of autonomy and lethality have already been deployed in numerous states. ${ }^{47}$ One such system includes the Patriot Advanced Capability (PAC) system. The PAC system is able to select, target and hit incoming missiles, small aircraft and drones, without human intervention. ${ }^{48}$ The system does not operate entirely independently: up to three officers watch over it at all times from what is called an Engagement Control Centre (ECS). The operators can let the system run in automatic mode but they are able to intervene to deselect or choose targets. Human involvement is therefore present, but largely as a backup. Both the operator and computer are able to make decisions on whether an incoming entity is a friend or an enemy. ${ }^{49}$ Whilst the previous PAC-2 system relied on the ECS for guidance once launched, the latest PAC-3 missile also includes its own radar transmitter and guidance computer, allowing it to guide itself once launched and therefore allowing it to change course if necessary. ${ }^{50}$

Perhaps one of the 'most' autonomous systems out there is the Samsung SGR-A1. The SGRA1 is an immobile sentry gun deployed on the border between North and South Korea. ${ }^{51}$ The system can detect potential enemies using infra-red up to $4 \mathrm{~km}$ away. It uses a low light

\footnotetext{
${ }^{44}$ UN General Assembly, Report of the Special Rapporteur on extrajudicial, summary of arbitrary executions, Christof Heynes UN Doc A/HRC/23/47 (9 April 2013), para. 38. See also U.S. Department of Defence, Autonomy in Weapons Systems Directive 3000.09 (21 November 2012); UK Ministry of Defence, The UK Approach to Unmanned Aircraft Systems Joint Doctrine Note 2/11 (30 March 2011); Human Rights Watch, Losing Humanity: The Case Against Killer Robots (2012) at 2.

${ }^{45}$ UK House of Commons, HC Deb, 17 June 2013, c729,per Nia Griffith MP.

${ }^{46}$ Convention on Certain Conventional Weapons CCW/MSP/2014, Para 21.

47 BBC, Fact File: Patriot Missile Defence (online) 2003, <http://news.bbc.co.uk/1/hi/world/2868569.stm> (accessed 11 April 2017).

${ }^{48}$ Raytheon, Global Patriot Solutions (online) <http://www.raytheon.com/capabilities/products/patriot/> (last accessed 2 December 2017); Lockheed Martin, Patriot Advanced Capability-3 (online) <http://www.lockheedmartin.co.uk/us/products/PAC-3.html> (accessed 2 December 2017).

49 Marshall Brain, How Patriot Missiles Work (online) How Stuff Works $<$ http://science.howstuffworks.com/patriot-missile.htm> (accessed 8 April 2017).

50 Global Security, Patriot Advanced $\quad$ Capability-3 <http://www.globalsecurity.org/space/systems/patriot-ac-3.htm> (accessed 2 December 2017).

51 Jean Kamagai, A Robotic Sentry for Korea's Demilitarized Zone IEEE (online) Spectrum 2007 $<$ http://spectrum.ieee.org/robotics/military-robots/a-robotic-sentry-for-koreas-demilitarized-zone> (accessed 2 December 2017); Jon Rabiroff, Machine gun-toting robots deployed on DMZ (online) Stars and Stripes 2010 $<$ https://www.stripes.com/news/pacific/korea/machine-gun-toting-robots-deployed-on-dmz1.110809\#.WPtv3dLys2w> (accessed 02 December 2017).
} 
camera and pattern recognition software to determine whether a target is human, animal or matter. The SGR-A1 also uses voice recognition software to identify approaching persons. It can command someone to surrender and to not move closer. It can then, accordingly, when the person gets within $10 \mathrm{~m}$ of the system, choose to sound an alarm or fire either rubber or real bullets. Whilst this decision is usually to be made by a human who watches over the system, the system does have a fully automatic mode where it can be set to decide itself. ${ }^{52}$

While some automatic or semi-autonomous weapons systems clearly already exist and are in use, full autonomy is a long way off. Autonomy is distinguished from automation - with automated systems being pre-programmed machines used to perform specific tasks and autonomous machines being able to make decisions themselves in changing and diverse conditions, thus being able to select from multiple options as opposed to being predictable in their processes. ${ }^{53}$ Thus, whilst automated machines may be 'making decisions' whether to fire or not, they do not make thought out decisions as they ultimately work through binary algorithms in a specific, set environment, never learning from their behaviour. Automated systems supposedly do what they are told to do: they are predictable in as much as they will act as predicted within the set of conditions predicted when they were made. Thus, according to Jeangène Vilmer, the sorts of systems discussed above are automated, not autonomous. ${ }^{54}$ Despite this, the debate as to whether these machines are actually automated or autonomous is contentious. Ambassador Michael Biontino of Germany has highlighted the difficulties of definition here, noting that "there are a number of different proposals as to where to draw the line between "autonomous" and "automated"... and probably, our understanding as to where to draw this line will even evolve over time as technological advances are made'. 55

At the international level, levels of autonomy are discussed in terms of whether the system includes the human in, on or out-of-the-loop. ${ }^{56}$ Human-out-of-the-loop machines are machines which independently select targets without supervision. Jeangène Vilmer states that these machines only currently exist against solely material targets, with electronic jamming systems being an example. ${ }^{57}$ These types of systems are then distinguished from human-inthe-loop systems and human-on-the-loop systems. Human-in-the-loop systems are systems where the decision to fire is made by a human, whereas human-on-the-loop is defined as those which 'independently designate and process tasks while fully under the supervision of a human, capable of interrupting its actions', ${ }^{58}$ PAC being an example here. All these categories sit somewhere between the lines of autonomy and automation. The debate around autonomous weapons at the international level, therefore, is mostly about whether humanout-of-the-loop systems should be allowed and to what extent. Human-out-of-the-loop systems are thus considered to be the dangerous types of machines, with the assumption being that these systems do not yet exist and that this paradigm amounts to autonomy.

52 Global Security, Samsung Techwin SGR-A1 Sentry Guard Robot (online) <http://www.globalsecurity.org/military/world/rok/sgr-a1.htm> (accessed 2 December 2017).

${ }^{53}$ Cummings above note 10 at 3.

54 Jean-Baptiste Jeangène Vilmer, Terminator Ethics: Should We Ban "Killer Robots"? (online) Ethics and International Affairs 2015 <http://www.ethicsandinternationalaffairs.org/2015/terminator-ethics-ban-killerrobots/> (accessed 26 February 2017).

55 General Statement made by Ambassador Michael Biontino, Representing Germany, Swiss Ambassador's Conference, Security in Uncertainty: New Approaches to Disarmament, Arms Control and Non-Proliferation Geneva 2016.

${ }^{56}$ Campaign to Stop Killer Robots above note 43.

57 Jeangène Vilmer above note 54.

${ }^{58}$ As above. 
However, whether autonomous weapons yet exist or not depends on perspective. Jeangène Vilmer, for example, defines PAC-3 as a human-on-the-loop system as it is fully automated yet always supervised by a human. ${ }^{59}$ The PAC-3 system, however, can independently select targets, decide whether a target is an enemy target or not, fire and accurately target even once released. Such a system could be defined as autonomous depending on how autonomy is defined. While the human does remain on-the-loop, the system does not require this to work. It seems that PAC-3, however, could possibly not be defined as autonomous as it works in specific conditions based on a set of algorithms as opposed to making complex decisions and learning. However, it is unclear at what point algorithmic programming may become so advanced that it becomes, in effect, a complex decision-making process. In addition, noting that a machine works on algorithms does not make that machine predictable, as shown by the Wikipedia algorithms which are correcting and deleting one another's information in unforeseen ways. ${ }^{60}$ Machines and algorithms do not always work as they are supposed to, begging the question of at which point such unexpected algorithmic behaviour may amount to autonomy. Thus, as Jeangène Vilmer notes these three descriptions of human in/on/out the loop 'simplif[y] matters and do... not take into account the fact that autonomy does not consist of three levels, but rather it is a continuum of many degrees'. ${ }^{61}$ These three categories are in many ways false and unhelpful. The same can be said, too, of definitions of autonomy and automation, in that 'these two categories are neither mutually exclusive nor homogeneous. There is no absolute distinction between automation and autonomy, but rather a continuum between the two'. ${ }^{62}$ PAC-3 and SGR-A1 systems, for example, are already bridging this automated/autonomous distinction in that their programming is so complex that it can be seen as a very low level decision making process.

Part of the problem with the autonomy debate is that it tries to separate the machine from the human from the outset. Either the human is in the loop and thus controlling the machine, or on the loop, prevailing with ultimate control, or out of the loop, thus posing the machine as 'other', distinct and separate from the human. However, ultimately, these machines are all deeply connected to and work with the human in various ways, either through being operated by a human or, at the more advanced level, having been programmed by a human. Technology is changing the way we delegate tasks and make decisions but there is still human choice, even if in the programming alone.

It is clear, however, that for a system to be fully autonomous, i.e. able to create itself and others, some form of high-level intelligence would be needed. Artificial intelligence (AI), although hard to define precisely, is the possibility of the creation of an intelligent artefact. ${ }^{63}$ What intelligence means, however, is debatable. Theories include those which state that AI would have to be able to learn from experience to those which state that AI must be able to make connections and assumptions like a human can. ${ }^{64}$ The Turing Test is often cited here as an appropriate measure of intelligence. Created in the 1950s, the Turing Test states that a machine should be considered to be intelligent if a human believes it to be another human. ${ }^{65}$ This test has been shown to be faulty, however, with Dennett highlighting how many people

\footnotetext{
${ }^{59}$ As above.

${ }^{60}$ Ian Sample, Study reveals bot-on-bot editing wars raging on Wikipedia's pages (online) Guardian 2017

<https://www.theguardian.com/technology/2017/feb/23/wikipedia-bot-editing-war-study> (accessed 2 December 2017).

${ }^{61}$ Jeangène Vilmer above note 54.

${ }^{62}$ Ibid.

${ }^{63}$ James Fetzer, Artificial Intelligence: Its Scope and Limits (Springer 1990) at 3.

${ }^{64}$ See Matt Ginsberg, Essentials of Artificial Intelligence (Morgan Kaufmann 2013) at 4.

${ }^{65}$ Alan Turing, 'Computing machinery and intelligence' (1950) 59 Mind 433.
} 
can be easily tricked into believing a fairly simple machine is human. ${ }^{66}$ Yet as Ginsberg notes, the Turing Test may have its flaws - such as the human being too lazy to question the entity fully - yet it remains one of the most accepted tests of intelligence. ${ }^{67}$ Ginsberg argues that this is because the test is difficult and thus sets a 'reasonably sharp description of intelligence', requiring the machine to discuss a very broad array of subjects. ${ }^{68}$ The Turing Test, however, is a test of speech and not necessarily the other actions which may be deemed to constitute human intelligence, including eye contact and body language. ${ }^{69}$ Since the test's creation in the 1950's, however, technology has dramatically advanced. The test also seems somewhat less rigorous in an age where technology is challenging ideas of what it means to be human. ${ }^{70}$ In light of this, it seems that the Turing Test is not the only standard through which AI is and should be defined. What AI is and what it could constitute is hotly debated. If algorithms work as binaries between 0 and 1, it seems that AI, in making choices, would navigate these binaries. As noted above, however, the point at which binaries become so complex that they may constitute enough to be deemed intelligence remains unclear.

AI plays a key role in theories of the singularity (the idea that machines will eventually surpass human intelligence), representing the possible superintelligence required for the singularity and an accelerated post-capitalist world to come about. ${ }^{71}$ Within weapons systems, however, AI presents a darker picture. A number of people have highlighted the risks around $\mathrm{AI}$ and the possibility that $\mathrm{AI}$, whether created or not to kill, may choose to kill. $^{72}$ In addition to this, AI as purposefully embedded into weapons technology would clearly move weapons systems towards 'full' autonomy of the kind where the robots may not only make decisions and learn but can also create and programme themselves. AI does not yet exist in the realm of autonomous weapons, although there are a number of AI programmes and machines (arguably) in existence that are also being developed and tested, again depending on one's definition of $\mathrm{AI}^{73}$ For the most part these programmes remain limited, lagging far behind what could feasibly be dubbed human intelligence with most machines able to perform only one specific task (even if they perform that task very well). ${ }^{74}$

\subsection{Legal-Ethico Debates on Autonomous Weapons Systems}

\footnotetext{
${ }^{66}$ Daniel C. Dennett, Brainchildren: Essays on Designing Minds (MIT Press 1998).

${ }^{67}$ Ginsberg above note 65 at 7.

${ }^{68}$ As above

${ }^{69}$ As above, although note that some AI can now make eye contact. See Hanson Robotics, Sophia: about me (online) 2017, <http://sophiabot.com/about-me/> (accessed 2 December 2017).

${ }^{70}$ Haraway above note 16.

71 Vernor Vinge, The Coming Technological Singularity: How to Survive in the Post-Human Era paper presented at Vision-21: Interdisciplinary Science and Engineering in the Era of Cyberspace Conference, NASA Lewis Research (1993), Centre, NASA Publication CP-10129, <https://ntrs.nasa.gov/archive/nasa/casi.ntrs.nasa.gov/19940022855.pdf> (last accessed 1 December 2017).

${ }^{72}$ Land above note 38.

${ }^{73}$ Elon Musk and Mark Zuckerberg, for example, disagree as to the definition of AI, with Zuckerberg defining AI broadly and thus stating that it exists already and with Musk seeing AI as being much more advanced and more akin to what some call a General Artificial intelligence (AGI) i.e. something which is intelligent across all areas, not just for one specific purpose. See; Artur Kiulian, Elon Musk and Mark Zuckerberg are arguing about AI - but they're both missing the point (online) Entrepreneur 2017 <https://www.entrepreneur.com/article/297861> (accessed 2 December 2017).

${ }^{74}$ Deep Blue being an example.
} 
To develop a feminist posthuman approach to autonomous weapons systems, there is a need to understand the existing debates concerning these systems. This section summarises the key debates in this area.

Many groups have called for a pre-emptive ban of autonomous weapons. These groups include NGOs and the UN Special Rapporteur on Summary or Arbitrary Execution. ${ }^{75}$ Further to this, in 2015, over 20,000 AI, robotics and technology researchers and public intellectuals signed a letter calling for a 'ban on offensive autonomous weapons beyond meaningful human control' ${ }^{76}$ Another ban was proposed in August 2017, this time by 116 robotics and AI company leaders from 26 countries. $^{77}$ A number of states, notably all from the Global South, have also called for banning autonomous weapons, including Pakistan, Bolivia, Egypt and Ghana. ${ }^{78}$ Over seventy religious leaders have called for a ban. ${ }^{79} \mathrm{~A}$ number of philosophers have also joined the anti-group, arguing that machines should not be able to make life/death decisions. ${ }^{80}$ A group of twenty Nobel Peace Prize winners called for a ban in 2014, and in the same year, the European Parliament adopted a non-binding resolution calling on Ministers of the EU and the EU's High Representative of Foreign Affairs and Security to ban such weapons. ${ }^{81}$

There are various legal, ethical and military debates around autonomous weapons. ${ }^{82}$ Arguments include that the removal of humans from the field could drastically increase states' willingness to go to war due to the heavily reduced risk of military casualties. ${ }^{83}$ Other arguments state that autonomous weapons could lead to a reduction in casualties as they do not have emotions and will thus never feel the need to uphold a 'shoot first ask questions later' policy. ${ }^{84}$ The larger legal concern about these systems is whether a machine would ever be able to uphold International Humanitarian Law (IHL). Humans already make mistakes and break IHL, and there is very little doubt that machines would as well. Whilst roboticist expert Ron Arkin has argued that machines may better uphold the standards of IHL than humans, such an argument lacks nuance. ${ }^{85}$ As Jeangène Vilmer notes, 'roboticists often exaggerate their ability to program IHL and convert legal rules into algorithms. Non-jurists often have a

\footnotetext{
${ }^{75}$ UN General Assembly, 'Report of the Special Rapporteur on extrajudicial, summary of arbitrary executions, Christof Heynes,' UN Doc A/HRC/23/47 (9 April 2013); Campaign to Stop killer Robots, Homepage (online) $<$ https://www.stopkillerrobots.org/> (accessed 13 February 2018); Article 36, Autonomous Weapons (online) <http://www.article36.org/issue/autonomous-weapons/> (accessed 13 February 2018).

${ }^{76}$ Future of Life Institute, Autonomous Weapons: An Open Letter from AI and Robotics Researchers (online) $<$ https://futureoflife.org/open-letter-autonomous-weapons> (accessed 10 July 2017).

${ }^{77}$ Future of Life Institute, An Open Letter to the United Nations Convention on Certain Conventional Weapons (online) 2017 <https://futureoflife.org/autonomous-weapons-open-letter-2017> (accessed 3 December 2017).

78 See Campaign to Stop Killer Robots, Country Views on Killer Robots (online) March 2016 <http://www.stopkillerrobots.org/wp-content/uploads/2013/03/CountryViews_Mar2016-1.pdf> (accessed 10 July 2017).

79 Pax for Peace, Religious leaders call for a ban on killer robots (online) 12 November 2014 <https://www.paxforpeace.nl/stay-informed/news/religious-leaders-call-for-a-ban-on-killer-robots> (accessed 10 July 2017).

${ }^{80}$ See for example, Sparrow above note 23; Asaro above note 23.

${ }^{81}$ Nobel Women's Initiative, Nobel Peace Laureates call for Preemptive Ban on "Killer Robots" (online) 12 May $2014 \quad<$ https://nobelwomensinitiative.org/nobel-peace-laureates-call-for-preemptive-ban-on-killerrobots/?ref=204> (accessed 10 July 2017); European Parliament Resolution on the use of Armed Drones 25 February 2014 2014/2567(RSP) Section 2(d).

${ }^{82}$ See for example; Krishnan above note 25; Schulzke above note 25; Jack M. Beard, 'Autonomous Weapons and Human Responsibilities' (2014) 45(3) 617; Roff above note 25; Scharre above note 25.

${ }^{83}$ Heyns above note 75.

${ }^{84}$ Ron Arkin, 'Lethal Autonomous Systems and the Plight of the non-combatant,' (2013) AISB Quarterly 137.

${ }^{85}$ As above.
} 
simplistic understanding of the rules, reducing them to univocal commands' ${ }^{86}$ IHL does not apply through binary choices but rather requires a balanced assessment of principles, perspectives and ethical standpoints. ${ }^{87}$

One example of the way in which IHL does not just apply mathematically can be seen in the principle of proportionality, which requires 'incidental loss of civilian life, injury to civilians, damage to civilian objects' to be balanced against 'the concrete and direct military advantage anticipated'. ${ }^{88}$ Yet determining what is proportionate or not is not simply a matter of logic. Proportionality requires a deep understanding of nuance, as shown by the number of legal debates surrounding this principle. ${ }^{89}$

Another part of IHL which requires applying a nuanced reflection can be found under Article 57(2) of the 1977 First Additional Protocol to the Geneva Conventions, which requires that the risk of civilian life should be minimised at all times and, in line with this, states must review the different forms an attack may take. ${ }^{90}$ In order to abide by international legal obligations, these machines would have to be able to determine whether targets are military targets or not (and thus whether humans are military personal or civilians) and to make assessments on how to reduce damage in the most effective way possible, a decision which requires extremely intelligent thinking. For example, determining whether something is a rifle or an umbrella from a distance can be difficult. ${ }^{91}$ Such a dilemma could not be easily evaded through creating a system which can read the code number on the side of weapons: first, this excludes analysis of unarmed civilians within the calculation, and second, not every person who carries a weapon is a combatant. In conflict situations, it can be common for civilians to carry weapons for self-defence, and if peacekeepers are present, they may also carry weapons, thus complicating identification more. ${ }^{92}$ Further, even if a system were able to distinguish effectively between combatants and non-combatants, it would then also need to be able to understand when someone surrenders, in line with IHL. ${ }^{93}$ It would also need to be able to determine when someone is seriously injured and split off from their group, thus making them an illegitimate target under IHL. ${ }^{94}$ It is difficult to imagine a machine being able to make decisions such as these without it being highly intelligent.

Another key issue here is of accountability. Accountability when IHL is breached could be hard to determine where an autonomous weapon is involved, as the responsibility may lay across many actors. For example, if a machine kills an innocent person independently, should the military commanding the robot be held accountable? Or rather the manufacturer, the inventor, the commander, the programmer, or even in the case of AI machines, the robot itself? There is the further question of whether these machines are, in their very existence, compatible with IHL at all. Article 36 of Additional Protocol I of the Geneva Conventions

\footnotetext{
${ }^{86}$ Jeangène Vilmer above note 54.

${ }^{87}$ Heyns above note 75 at para. 55 .

${ }^{88}$ International Committee of the Red Cross (ICRC), Protocol Additional to the Geneva Conventions of 12 August 1949, and relating to the Protection of Victims of International Armed Conflicts (Protocol I) 1125 UNTS 38 June 1977 Article 51(5)(b); Rome Statute of the International Criminal Court 17 July 1998 ISBN No. 92-9227-227-6 Article 8(2)(b)(iv).

${ }^{89}$ See in general Michael Newton and Larry May, Proportionality in International Law (Oxford University Press 2014).

${ }^{90}$ ICRC above at note 88 Article 57(2).

${ }^{91}$ Sparrow above note 23.

${ }^{92}$ As above at 101-2.

${ }^{93}$ ICRC above at note 88 Article 41.

94 As above.
} 
states that all weapons systems must be verified as compatible with IHL before being used. ${ }^{95}$ This debate also invokes the Marten Clause, which states that 'civilians and combatants remain under the protection and authority of the principles of international law derived from established custom, from the principles of humanity and from the dictates of public conscience'. ${ }^{96}$ Whilst there is great debate as to what the Martens Clause means and how it exactly applies, it is questionable whether a machine being allowed to make life or death decisions may be in line with the principles of humanity and public conscience, with scholars taking positions on both sides of the debate. ${ }^{97}$

There are many debates around the potential use of autonomous weapons. There have also been many proposals as to how to deal with them. As noted above, one proposal is to ban these systems. Bans are often justified on the basis of the need to retain 'meaningful human control', ${ }^{98}$ though there is little clarity around what constitutes human control. ${ }^{99}$ Any ban may prove difficult to enforce given the nuances in definition between autonomy and automation. ${ }^{100}$ Parties wanting autonomous weapons draw on the lack of definitional clarity to promote their own agendas. ${ }^{101}$ These ambiguities are used to deter any debate on weapons systems which do not meet "high-levels" of autonomy, even though such systems clearly still pose vast ethical dilemmas. Jeangène Vilmer thus believes that a better and 'wider option is to install safeguards'. ${ }^{102}$ One of the safeguards he proposes is to only allow these weapons to be used against material targets such as tanks and aircraft. ${ }^{103}$ Vilmer argues that such a restriction avoids the problem of allowing systems to decide whether someone is a combatant or a civilian. ${ }^{104}$ However, the clear problem with this position is that anti-material machines can still kill people, as people are often in/with/next to material.

Alternatively, Arkin has proposed regulation of autonomous weapons via a test. ${ }^{105}$ The Arkin Test states that a machine can be employed when it can be shown that it can respect the laws of war as well or better than a human in similar circumstances. ${ }^{106}$ Some scholars have argued that if a machine passes this test, we have a moral obligation to deploy it, as it may work to uphold IHL better than ever before. ${ }^{107}$ There are many opponents to such a test. Sparrow, for example, has noted that Arkin's argument 'depends on adopting a consequentialist ethical framework that is concerned only with the reduction of civilian casualties'. ${ }^{108}$ Thus, while such a machine could be justified based on statistics, this avoids the fact that the IHL standard for the protection of civilian life should be perfection. Noting that a machine may

\footnotetext{
${ }^{95}$ As above Article 36.

${ }^{96}$ As above Article 2(1).

${ }^{97}$ For various submissions as to what the Martens Clause means, see for example Legality of the Threat of Use of Nuclear Weapons (1996) Advisory Opinion I.C.J. Reports 1996 226. See also Peter Asaro, 'Jus nascendi, robotic weapons and the Martens Clause' in Ryan Calo et al (eds) Robot Law (Edward Elgar Publishing 2016) 367; Jeangène Vilmer at note 54.

${ }^{98}$ Campaign to Stop Killer Robots above note 43; Biontino, above note 56; Lord Astor of Hever (Parliamentary Under Secretary of State, Defense; Conservative), House of Lords debate, 26 March 2013, Column 960; U.S. Department of Defense above note 44.

${ }^{99}$ UK Ministry of Defence above note 44; U.S. Department of Defense as above.

${ }^{100}$ Arkin above note 84 at 6.

${ }^{101}$ See Campaign to Stop Killer Robots above note 43.

102 Jeangène Vilmer above note 54

${ }^{103}$ As above

${ }^{104}$ As above

${ }^{105}$ Arkin above note 84 .

${ }^{106}$ Ronald Arkin, Governing Lethal Behaviour in Autonomous Robots (Routledge 2009); Ronald Arkin, 'The Case for Ethical Autonomy in Unmanned Systems' (2010) 9(4) Journal of Military Ethics 332.

${ }^{107}$ George R. Lucas, 'Automated Warfare' (2001) 25(2) Stanford Law \& Policy Review 322 at 322, $326,336$.

${ }^{108}$ Sparrow above note 23 at 16.
} 
kill less does not make those deaths acceptable. ${ }^{109}$ Further to this, suggesting that these machines could follow IHL better than humans ignores the fact that IHL is not just a set of clear cut rules but requires very complex decision-making processes, ${ }^{110}$ even within the confines of set Rules of Engagement. Arkin has suggested that these issues could be resolved with a backup system whereby the machine would refer to a human every time it has to make complex ethical decisions. ${ }^{111}$ However, the decision as to whether a machine is or should be in doubt or not also remains complex and mistakes could still be made, leading Sparrow to declare that 'if we can't trust a machine to reliably make ethical judgements, we cannot trust it to identify when its judgements might be unreliable'. ${ }^{112}$

\subsection{An Analysis of the Discourse on Autonomous Weapons Systems}

\subsection{Challenging the Humanist Discourse around Autonomous Weapons: A Posthuman Analysis}

Despite the challenges posed, calls for a ban remain strong. However, there are very large differences between the people who call for a ban. NGOs, for example, tend to take a humanitarian stance, noting the need to promote a humanist ethics and uphold the rules of IHL. Alternatively, however, there are those in this group who do not fundamentally come from a humanist background but come from the perspective of futurism. ${ }^{113}$ Whilst the position of NGOs comes from the humanist discourse of IHL and the need to protect human life over all others, aligning more with the human dignity standpoint of religious leaders, some tech experts like Elon Musk fully embrace the posthuman future while working to ensure that this future remains ethical, albeit working within the confines of capitalism. ${ }^{114}$

The will to construct the future from the now can be seen through the project OpenAI, which Musk co-founded. ${ }^{115}$ OpenAI is a project which seeks to disrupt the current corporate trend in AI research, where most of the research into AI is being done by large companies such as Google or in research centres such as MIT, with many of the findings of this research kept private in the hope of using them for profit. OpenAI is a non-profit organisation which seeks to disrupt corporate monopolies on AI research by committing to make all of its research and patents public, as well as through offering to work freely with any group or organisation. ${ }^{116}$ Noting the threat AI could pose to humanity, OpenAI aims to create a friendly General

\footnotetext{
${ }^{109}$ As above

${ }^{110}$ As above; Jeangène Vilmer above note 54.

${ }^{111}$ Arkin above note 106; Jeangène Vilmer as above.

${ }^{112}$ Sparrow above note 23 at 107.

${ }^{113}$ By 'futurism' I mean the embrace of technology and the wish to use it to craft the future as opposed to the $20^{\text {th }}$ century Italian movement. This is my view of Musk, not his own. The London Futurists perhaps epitomise what I am referring to here. For a personal account of attending London Futurists meetings, see Mark O'Connell, To Be a Machine: Adventures Cyborgs, Utopians, Hackers and the Futurists Solving the Modest problem of Death (Granta 2017).

${ }^{114}$ By 'the confines of capitalism' I am referring to the fact that Musk and those like him seem to seek to make a profit. To some extent this can be understood as a way of using the existing system for change. However, there are other tech movements which actively seek to rebut technology's capitalist tendencies. See, for example, Grinders who practise DIY biohacking i.e. using science and technology to hack their bodies. The Grinders believe in open source transhumanism and the need to make biohacking accessible to all, outside the confines of corporate power. See Biohack.me, Who We Are (online) <http://www.biohack.me> (accessed 30 January 2018).

115 See Dave Gershgorn, New 'Open AI' Artificial Intelligence Group Formed by Elon Musk, Peter Thiel, and

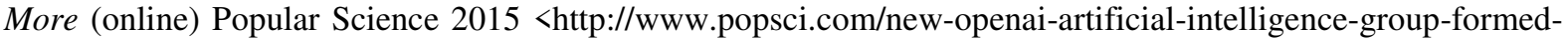
by-elon-musk-peter-thiel-and-more $>$ (accessed 3 December 2017).

${ }^{116}$ Open AI, Mission (online) <https://openai.com/about/\#mission> (accessed 3 December 2017).
} 
Artificial Intelligence (GAI) - a system which can do more than just one thing such as speak or play chess; one which has 'human' characteristics. ${ }^{117}$ OpenAI thus represents a clear, strategic effort to disrupt current trends in technology and AI development, including the will to make profit, aiming to bring a different ethical standpoint to the realm of AI research working, hopefully, to create a better future. ${ }^{118}$

All the groups who call for a preventative ban fundamentally agree that machines should not make life/death decisions. However, while NGOs seek to protect humans now within the confines of the present, with the risk of becoming out of date, futurist tech experts fundamentally believe that 'the best way to predict the future is to invent it' ${ }^{119}$ OpenAI represents a move towards shaping technological advancement now to prevent the existence of killer machines. Such aims are very similar to xenofeminist aims: the wish to appropriate technology for feminist aims. Whilst xenofeminism does not explicitly address the threat to life technology could pose, I argue that the wish to define and use technology for feminist aims inherently includes the wish to ensure that technology remains 'friendly'. ${ }^{120}$ While OpenAI wishes to create a friendly AI, however, they do not explicitly define what 'friendly' means. Xenofeminism, on the other hand, is explicitly informed by a feminist ethos which seeks to ensure that 'friendly' means non-killer as a minimum. There is a need, as I will suggest, to bring these two bodies of thought together. Gender theory is required in this area due to its long history of theorising and applying a set of complex and nuanced tools which seek to promote equality and justice, these ethics forming what I argue should constitute 'friendly' technology.

While there is a need to ensure that IHL is upheld and that robots do not kill, it is also clear that this ethical dilemma does not just apply to autonomous weapons. While the organisations mentioned above clearly have at least some form anti-militarism as a core aim, ${ }^{121}$ the temporal horizon of such NGOs remains limited. NGOs largely maintain a strict humanist stance, focusing on the realm of international law and the need to promote and protect existing legal frameworks such as IHL which situate the human at the centre of the paradigm. Whilst this has historically produced many great achievements, such a humanist stance cannot be applied given the rapid pace at which technology is now developing. AI may not only pose a threat to the lives of humans where designed, purposefully, to kill, but may also pose a threat to life in and of itself, as it exists. There is a need for all groups who are working to promote ethical technologies to consider not only what may seem attainable now, but what is feasibly attainable in the future, noting the ways in which the now can be used to construct the future.

NGOs continue to situate the human as the centre of their paradigm, seeing the machine as the 'other' to the human. This can be seen in the way in which autonomy is discussed in relation to the human who is imagined as either in/on/out of the loop, which does not account for the ways in which humans and machines work in connection. ${ }^{122}$ Posthumanism, on the other hand, challenges the centrality of the human within Western thinking, working to re-

\footnotetext{
${ }^{117}$ Eliene Augenbraun, Elon Musk: Artificial Intelligence may be "more dangerous than nukes" (online) CBS News $2014<$ http://www.cbsnews.com/news/elon-musk-artificial-intelligence-may-be-more-dangerous-thannukes/> (accessed 3 December 2017).

${ }^{118}$ Cade Metz, Inside Open AI, Elson Musk's Wild Plan to Set Artificial Intelligence Free (online) Wired 2016 $<$ https://www.wired.com/2016/04/openai-elon-musk-sam-altman-plan-to-set-artificial-intelligence-free/> (accessed 3 December 2017).

${ }^{119}$ Alan Kay as quoted in OpenAI website, OpenAI above note 116.

${ }^{120}$ I use the term "friendly" as this is the term used by OpenAI.

${ }^{121}$ See for example Reaching Critical Will above note 35.

${ }^{122}$ Haraway above note 16.
} 
think the human/machine binary. Feminist posthumanism notes that something else is needed; a new way of defining subjectivity which sees the complexities and interconnections between humans and others: nature, technology, animals, etc., rejecting the human as the central paradigm and noting how the human is located instead in the flow of relations with multiple others'. ${ }^{123}$ The humanist discourse around autonomous weapons ignores the posthuman reality that humans and machines are already working in connection with one another. Life/death decisions are already being made by human-machine combinations, as the next section illustrates. Banning autonomous weapons is not enough: there is a need to consider the ways in which machines are already making these decisions and to create ethical frameworks for these and future technologies, rebutting the false exceptionalisation which surrounds the current discourse on autonomous weapons.

\subsection{Machine-Human Life/Death Decision Making}

As Jasanoff notes, technology is based around a set of decisions. ${ }^{124}$ Jasanoff observes that we often do not question these decisions until there is an accident - at which point we find who made the mistake. ${ }^{125}$ However, she argues that people 'have spent a great deal more energy thinking about how to make good laws than about how to design good technological objects'. ${ }^{126}$ Yet, she continues, 'in democratic societies, uncontrolled delegation of power is seen as a basic threat to freedom'. ${ }^{127} \mathrm{We}$ must 'understand how power is delegated to technological systems'. ${ }^{128}$

The need to understand how power and decision-making are delegated to technology is ever more urgent in the realm of life/death decision-making. However, as noted, the humanist discourse on autonomous weapons fails to account for the ways in which humans and machines are already working together to make life/death decisions. The most obvious example is the use of programming and algorithms in drone warfare. While many drone strikes are conducted as 'personality strikes' - i.e. strikes on a particular, key, well-known person - these occur only a few times a year, with 'signature strikes' happening a few times a week. ${ }^{129}$ These attacks are conducted on the basis of a 'pattern of life' analysis. 'Pattern of life' analysis develops a profile of an individual or a network of individuals by drawing on all the intelligence available, which includes things like drone and other aerial surveillance intelligence, communications interceptions, as well as phone tapping information and GPS tracking information. ${ }^{130}$ What becomes clear in 'drone warfare', therefore, is that the drone itself is only one part of a broader system which includes big data, algorithms, intelligence collection, chains of command, and bureaucratic formations, among other technologies and practices. ${ }^{131}$ This data is then often combined with individual tracking through the use of mobile phone and GPS tracking systems in order to both watch movements as well as to

\footnotetext{
${ }^{123}$ Braidotti above note 2 at 50 .

${ }^{124}$ Jasanoff above note 37.

${ }^{125}$ As above.

${ }^{126}$ As above.

${ }^{127}$ As above at 11-12.

${ }^{128}$ As above at 12 .

${ }^{129}$ Wilcox, above note 36 (2015) at 129.

${ }^{130}$ Ian Shaw, 'Predator Empire: The Geopolitics of US Drone Warfare' (2013) 18 Geopolitics 536 at 550; Cora Currier, The kill chain: The lethal bureaucracy behind Obama's drone war (online) The Intercept 2015 $<$ https://theintercept.com/drone-papers/the-kill-chain/> (accessed 3 December 2017).

${ }^{131}$ Wilcox (2016) above note 36 at 5.
} 
target individuals. ${ }^{132}$ The gathering of this information builds up to create a file of information collected by machines which, as Chamayou has noted 'once it becomes thick enough, will constitute a death warrant'. ${ }^{133}$ This is an example of part-machine life/death decision-making. Part of the decision-making process here is already done by machines which gather this data and predict the likelihood of an individual's involvement with terrorist organisations. While the human is clearly involved, in that they then must note the results of the data collected, deem it enough to act upon and then operate the drone to kill the subject in question, the machine and the human are making life/death decisions together. It is also worth nothing, as Wilcox has shown, the ways in which this data is often interpreted in racialised and gendered ways. ${ }^{134}$

Such processes of human-machine life/death decision-making would not be covered under a ban of autonomous weapons. It thus seems that part of the problem with the debate around autonomous weapons is the debate around autonomy itself. By trying to define autonomy instead of working to understand automation and autonomy as in continuum, international debates on autonomous weapons other the machine from the human, creating a false paradigm. Such a limited account of autonomy works to set the standard so high for machine decision-making that, in the end, almost nothing may be covered under a ban. In the meantime, machines are already making of life/death decisions alongside humans. Machine involvement in such decision-making processes is only set to increase, as the next section will illustrate.

\subsection{Cyborg Super Soldiers}

As Vinge states, 'in humans, the hardest development problems have already been solved. Building up from within ourselves ought to be easier than figuring out first what we really are and then building machine that are all of that [as per AI]'. ${ }^{135}$ While beyond human intelligence is often discussed in reference to AI, this is only one model. In fact, superintelligence and the singularity following it is likely to occur through what Vinge defines as Intelligence Amplification (IA). IA may include, for example, large computer networks waking up and becoming superhumanly intelligent or 'computer/human interfaces may become so intimate that users may reasonably be considered superhumanly intelligent'. ${ }^{136}$ These two examples are different to AI as they either come from 'upgrading' the human or from the computer finding its own intelligence rather than coming from a specially created machine.

Given current trends and advancements in both wearable military technologies and human enhancement technologies, in contrast to the vast technological problems in creating a humanoid killer robot, the future of autonomous weapons may lie more in the enhancement of human soldiers than in the machinic 'other'. Superhuman soldiers, however, would not be covered under the kinds of legal bans being proposed. Of course, such a soldier would not necessarily be called a weapon and would pose a different set of legal and ethical questions considering that the entity would remain human to some extent, possibly retaining human choice capacity and empathy. ${ }^{137}$ However, it is also unclear at what point a technologically

\footnotetext{
${ }^{132}$ Jeremy Scahill and Glenn Greenwald, The NSA's secret role in the U.S. assassination program (online) The Intercept $201<$ https://theintercept.com/2014/02/10/the-nsas-secret-role/> (accessed 3 December 2017).

${ }^{133}$ Grégoire Chamayou, A Theory of the Drone (trans Janet Lloyd) (The New Press 2015) at 49.

${ }^{134}$ Wilcox, above note 36 .

${ }^{135}$ Vinge above note 69.

136 As above.

${ }^{137}$ Anxieties around what and who counts as human in relation to human enhancement technologies are already garnering attention, such anxieties being only set to increase in intensity as human enhancement technologies
} 
enhanced human may be deemed to be more machine than human. For example, as noted above, emotions in military contexts are often deemed to be a weakness by many who then use this argument to justify autonomous weapons. ${ }^{138}$ Following this line of argument, it is feasible to consider that attempts may be made to make superhuman soldiers emotionless to make them more efficient. It is at this point - where some parts of the soldier's humanity may be lost - that the ethics of autonomous weapons may begin to apply directly to cyborg soldiers. Superhuman soldiers thus exemplify the false binaries between autonomy and automation and the human and the machine in that they will likely embody all these things at once in a very direct way.

Recent trends in military technologies exemplify the trend towards creating enhanced human cyborg super-soldiers. Wearable military technologies are being developed to make human soldiers more efficient, as with exoskeletons. Designed to make soldiers stronger and to help disabled soldiers get back to work, the development and use of exoskeletons is one step towards the creation of super-soldiers. ${ }^{139}$ Many of these wearable military technologies are being used not only to increase strength but to make life/death decision making more efficient. An example of such a technology can be seen in the Boomerang gunfire location system. Boomerang pinpoints the exact location of incoming small arms fire using acoustic detection and sophisticated algorithms. This information is then related directly to the soldier who can choose whether to fire or not. ${ }^{140}$ Initially mounted onto trucks, there is now also a soldier wearable system called the Boomerang Warrior-X. While the system still requires a soldier to use the information given to choose whether to fire, these examples not only show the ways in which the human-machine are already working together to make life/death decisions, but also highlight the trend in working to create a new breed of super-soldier. If one merges the data collection and profiling used in drone warfare and gives this to a soldier in an exoskeleton using a system such as Boomerang Warrior-X, an early form of superhuman soldier can already be seen to be emerging.

While human enhancement technology is rather limited at this point, it is developing. One clear example of a research project which could contribute to the creation of superhuman soldiers can be seen in HRL's Information \& System Sciences Laboratory's transcranial direct current stimulation project. ${ }^{141}$ The researchers in this project 'measured the brain activity patterns of six commercial and military pilots and the transmitted these patterns into

advance. Contemporary anxieties were expressed, for example, over the debate around whether Oscar Pistorius, an athlete with prosthetic legs below the knee, could compete in the Olympics as opposed to the Paralympics. See Leslie Swartz, 'Cyborg Anxieties: Oscar Pistorius and the boundaries of what it means to be human' (2008) 23(2) Disability \& Society 187.

In the future, if technological subjects do gain personality, there could indeed be legal cases which ask the Courts to determine whether a subject is a human or an electronic subject. There is a great need to draw on scholars working on disability when it comes to these issues, especially those who note that disability is a socially constructed category and those who discuss the interaction between the body and matter. See for example Mike Oliver, Understanding Disability: From Theory to Practice (Palgrave Macmillan 2009); Jasbir K. Puar, 'Prognosis Time: Towards a Geopolitics of Affect, Debility and Capacity' (2009) 19 Women \& Performance: A Journal of Feminist Theory 161.

138 Arkin above note 84 .

${ }^{139}$ For more on exoskeletons and military use from a gender perspective see in this issue; Gina Heathcote, 'War's Perpetuity: Disabled Bodies of War and the Exoskeleton of Equality,' (2018) 44(1) Australian Feminist Law Journal.

${ }^{140}$ Raytheon, Boomerang (online) <http://www.raytheon.co.uk/capabilities/products/boomerang/> (accessed 11 March 2017)

${ }^{141}$ Jaehoon Choe et al., 'Transcranial Direct Current Stimulation modulates Neuronal Activity and Learning in Pilot Training' (2016) 10(34) Frontiers in Human Neuroscience 1. 
novice subjects as they learned to pilot an airplane in a realistic flight stimulator'. ${ }^{142}$ The study found that 'subjects who received brain stimulation via electrode-embedded head caps improved their piloting abilities' ${ }^{143}$ This demonstrates a possible way to decrease the time it takes to learn complex skills, given that 'commercial and military pilot training programs [already] now utilize flight simulation extensively for training basic flight and combat skills'. ${ }^{44}$ As the researchers on the project note, such a study could have massive 'benefits for commercial and military applications'. ${ }^{145}$ This exemplifies a further way in which technology is being developed in various contexts with the idea of creating superhuman soldiers.

Given current trends in wearable military technologies and the large investment in human enhancement technologies globally, as opposed to the vast technological problems in creating a humanoid killer robot, ${ }^{146}$ the future of autonomous weapons may not be solely machinic at all; rather, they are likely to take the form of a cyborg soldier. Discussions on autonomous weapons, however, continue to assert autonomous systems as the machinic 'other'. Such definitions which define these technologies before they exist may drastically limit the impact of any legal regulation despite the clear ethical and legal issues which arise from the possibility of any form of autonomous killer technology. It is clear that a feminist posthuman approach is needed on such technologies to ensure that the full range of technologies which may kill may be captured through legal regulation.

\subsection{Conclusions}

Despite current trends in military technologies and the ways in which machines are already helping to make life/death decisions, neither algorithmic 'independence', nor AI which decides to kill, nor any type of superhuman soldier would be covered under a pre-emptive ban of autonomous weapons. On the other hand, a posthuman approach to autonomous weapons would recognise the connections between the human and the machine. Such an approach would not fixate on autonomy but would instead work to break down the false dichotomies between autonomy-automation and human-machine, instead focusing on the ethical implications of killer systems across these lines. ${ }^{147}$ As noted above, whilst xenofeminism and posthuman feminism understand the dangers as well as the potentials of technology, xenofeminism in particular does not account for the power of militarism and the militarism-capitalism assemblage. It seems, therefore, that the risks of the technologymilitarism-capitalism assemblage need to be further read into xenofeminism to ensure that it stays true to its own aims of using and appropriating technology to construct an intersectional feminist future.

Braidotti's posthumanism pays attention to death and modes of dying while promoting an affirmative posthuman era in the face of the necropolitical. ${ }^{148}$ In contrast to the necropolitical

\footnotetext{
${ }^{142}$ Matthew Phillips as quoted in HRL Laboratories, HRL demonstrates the potential to enhance the human intellect's existing capacity to learn new skills (online) 2016 <http://www.hrl.com/news/2016/0210/> (accessed 10 July 2017).

${ }^{143}$ Choe et al, above note 141 .

${ }^{144}$ As above at 2.

${ }^{145}$ As above.

146 Jeangène Vilmer above note 54.

${ }^{147}$ Braidotti above note 2 .

${ }^{148}$ As above at 111; Archille Mbembe, 'Necropolitics' (trans. Libby Meintjes) (2003) 15(1) Public Culture 11.
} 
politics of death itself, ${ }^{149}$ Braidotti proposes 'a politics of life itself' ${ }^{150}$ which chooses to tackle the obstacles of the posthuman condition as they come. She thus states:

It is a constant challenge for us to rise to the occasion, to be 'worthy of our times', while resisting them, and thus to practise amor fati affirmatively. It is quite demanding to catch the wave of life's intensities in a secular manner and ride on it, exposing the boundaries or limits as we transgress them... Death is the ultimate transposition, though it is not final, as zoe carries on, relentlessly. ${ }^{151}$

It seems hard, however, to read autonomous weapons in the affirmative when weapons technologies kill people in ever more removed and de-personalised ways. Autonomous weapons, are/will be the child of the military economy. As Braidotti notes, however, to analyse in the affirmative is not to deny the horror of our times. Affirmation 'proposes a different way of dealing with' such horrors. ${ }^{152}$

I propose that xenofeminism provides an affirmative blueprint for embracing the current times. I have noted how xenofeminist method works to appropriate technology and existing political structures, bending them to feminist aims. ${ }^{153}$ While the current form of xenofeminism does not fully account for the links between technology and militarism, this does not mean that xenofeminism cannot accommodate such concerns. Xenofeminist method is an affirmative approach in that it notes the contradictions and risks in the posthuman condition and works to deconstruct them.

Thus, taking an affirmative posthuman-xenofeminist perspective, one which understands the ways in which the human and the machine are deeply interconnected, I wish to use xenofeminist method - the appropriation of technology for feminist aims - to propose a posthuman-xenofeminist discourse on autonomous weapons. While the XFM does not explicitly address the threat to life technology could pose, the wish to define and use technology for feminist aims, I have already suggested, inherently includes the wish to ensure that technology remains ethical. Taking this further, it is important to note that anti-militarism is a key part of the feminist project as exemplified by the Women's Peace Conference of 1915, to the feminist activism of Greenham Common to the ways in which Haraway, in her early foundational works, highlighted anti-militarism as a key feminist project. ${ }^{154}$ While there are many feminists who do not promote an anti-violence stance, choosing to fight as part of their feminism, for example, this does not preclude an anti-militarism stance in the realm of military technologies. ${ }^{155}$ Neither does an anti-militarism stance in this area wish to judge those who engage in fighting as part of their feminist project as 'not feminists', nor to associate feminism inherently with peace. Rather, in noting the history of anti-militarism within the international feminist project, I wish to suggest that there is a need to promote an

\footnotetext{
149 This is Braidotti's critique of Agamben's concept of 'bare life.' See; Braidotti as above at 120-1; Giorgio Agamben, Homo Sacer: Sovereign Power and Bare Life (Stanford University Press 1998).

${ }^{150}$ Braidotti as above at 120 .

151 As above at 130 .

${ }^{152}$ As above at 121 .

${ }^{153}$ Laboria Cuboniks above note 2.

${ }^{154}$ For an example of the history of feminist anti-militarism in international law see Otto above note 42 . For more general examples of anti-militarism feminism; Cynthia Enloe, Globalization and Militarism (Rowman and Littlefield 2016); Heathcote above note 33; Haraway above note 16.

${ }^{155}$ This can be seen in the many examples of Kurdish female combatants: Bethan McKernan The Kurdish Women Building a Feminist Democracy and Fighting ISIS at the same time (online) The Independent 2017 <http://www.independent.co.uk/news/world/middle-east/kurdish-woman-building-feminist-democrac-fightingisis-at-the-same-time-syria-kurdistan-rojava-new-a7487151.html> (accessed 3 December 2017).
} 
ethics of anti-militarism at the international structural level. This is precisely because of the ways in which militarism structures the global order, working to structure technological innovation and development alongside forces such as capitalism, colonialism and other power structures. Such a stance must therefore be contrasted to more contextual scenarios, where fighting may indeed be the best form of feminist response. In this sense, anti-militarism must be distinguished from an anti-violence position, with anti-militarism aiming to challenge the industrial, technologically crafted, capitalist driven military complex and with an antiviolence position calling more broadly for peace and non-violence. It thus follows, given the links between militarism, technological advancements and capitalism, that xenofeminism, as a project aiming to appropriate technology for feminist aims, must have regard for antimilitarism. A xenofeminist appropriation of technology must therefore include the desire to ensure that the technology of the now and future cannot be used either for military gains or for the taking of human or nonhuman life. ${ }^{156}$ Xenofeminist method provides an affirmative method for dealing with the current times and the issue of military technologies.

Drawing on the will to appropriate technology for feminist aims and to create the future from the present, manipulating, hacking and coding the system, it seems that the appropriation of technology includes ensuring that technology can only be developed in ethical ways. Technology is dependent on a set of programming choices which will shape machine intelligence as technology advances. What choices are made now, what programming choices are made in these current times, could structure the entire future of technology and machine intelligence. There is a need for feminist posthuman perspectives and xenofeminist infiltrations now.

The xenofeminists know well that it matters who makes those programming choices. As Haraway puts it, 'it matters which figures figure figures, which systems systematize systems' ${ }^{157}$ Noting that 'technology isn't inherently progressive', the xenofeminists call for an intervention in these choices. ${ }^{158}$ While intelligent machines could indeed be the end of humanity, such machines may not make such choices. It is important to get the now right in the hope of working towards a future where the machine-human can work together ethically. As Haraway notes, 'the machine is use, our processes, an aspect of our embodiment. We can be responsible for machines: they do not dominate or threaten us. We are responsible for boundaries; we are they'. ${ }^{159}$

The XFM advocates the infiltration of multiple discourses. ${ }^{160}$ I propose this could include law. I have argued that the discourse on autonomous weapons needs to be made posthuman, emphasising the links between the machine and the human and the ways in which seeing the autonomous weapon as the machinic other is a fallacy. Xenofeminist method calls for the appropriation of technology to promote, in Braidotti's terms, affirmative aims: constructing the future from the now. While many of the groups calling for a legal ban of autonomous weapons may be overlooking some of the nuances in the debate and definitions, their larger goal - to seek legal frameworks to regulate these systems - is an aim which can remain useful. After all, legal regulation is a core manner in which profit-making tech creators may be forced to shape their innovations in ethical ways. In other words, a xenofeminist method may include not only the appropriation of technology itself but also the frameworks which

\footnotetext{
${ }^{156}$ See Alaimo and Hekman, above note 15.

157 Donna Haraway, 'Anthropocene, Capitalocene, Plantationocene, Chthulucene: making Kin' (2015) 6 Environmental Humanities 159 at 160.

${ }^{158}$ Laboria Cuboniks above note 2 at Zero $0 * 02$.

${ }^{159}$ Haraway above note 16 at 215.

${ }^{160}$ Laboria Cuboniks above note 2 at Overflow $0 * 19$.
} 
regulate it. These frameworks are key in structuring future developments of technology, and thus work to appropriate technology through structuring the creation of technology from the outset. In line with xenofeminist method, therefore, I propose that a legal framework is needed to ensure that feminist ethics of anti-militarism, justice and intersectionality remain central to technological innovation. A feminist posthuman understanding of technology is required here: to ensure that the dark sides of technology are evaded whilst technology's positive, subjectivity challenging and capitalism destroying potential is maintained. There is a need to focus on the regulation of all technologies, given the real possibility that killer machines may be created in multiple ways.

There have been steps in other contexts towards creating broader ethical regulations for technology. This can be seen in the example of the European Parliament resolution of 16 February 2017, which makes recommendations to the Commission on Civil Law Rules on Robotics. ${ }^{161}$ The resolution is well thought out, considering a variety of issues around the legal regulation of technology and noting issues around liability, care robots, autonomous vehicles and privacy issues. ${ }^{162}$ The resolution calls for the urgent need to regulate technologies. ${ }^{163}$ While the resolution opens up debate on these issues, it is non-binding and seeks to regulate non-military technologies, thus upholding a false binary between military and civil technologies despite the clear cross-overs. As noted above, many civil technologies are originally created for military purposes, and there also remains a risk that civil intelligent technologies may decide to kill or may be easily adapted to make them kill. ${ }^{164}$ In addition, the resolution does not consider human enhancement technologies despite emerging developments in this area. This trend towards focusing on the immediate present and towards categorising military and non-military technologies separately is repeated throughout legal and policy attempts to regulate these technologies. There is an urgent need for a posthumanxenofeminist infiltration of the discussions around the legal regulation of technology, working to promote a future-facing feminist posthuman perspective which understands the cross-overs between civil and military technologies, the human and the machine, and autonomy and automation. While technology may be largely controlled at present by a capitalist elite with strong ties to militarism, this does not mean this technology will inevitably remain in their hands and under their control. By ensuring that basic ethical principles are applied now, through the application of laws to regulate programming choices and technological innovation in the present, technology can be shaped, working towards a post capitalist, fairer, more ethical and just, feminist world.

\footnotetext{
${ }^{161}$ European Parliament above note 17.

162 As above.

163 As above.

${ }^{164}$ Cummings above note 10 .
} 